\title{
Effects of Jatropha curcas oil in Lactuca sativa root tip bioassays
}

\author{
LARISSA F. ANDRADE-VIEIRA ${ }^{1}$, CAROLINA M. BOTELHO ${ }^{1}$, BRUNO G. LAVIOLA ${ }^{2}$, \\ MARCEL J. PALMIERI ${ }^{3}$ and MILENE M. PRAÇA-FONTES ${ }^{1}$ \\ ${ }^{1}$ Departamento de Biologia, Centro de Ciências Agrárias, Universidade Federal do Espírito Santo, \\ Alto Universitário, s/n, Guararema, Caixa Postal 16, 29500-000 Alegre, ES, Brasil \\ ${ }^{2}$ Empresa Brasileira de Pesquisa Agropecuária/EMBRAPA Agroenergia, \\ Parque Estação Biológica/PqEB, s/n, Asa Norte, 70770-901 Brasília, DF, Brasil \\ ${ }^{3}$ Departamento de Biologia, Universidade Federal de Lavras, \\ Campus Universitário, s/n, Caixa Postal 3037, 37200-000 Lavras, MG, Brasil
}

Manuscript received on February 2, 2013; accepted for publication on July 5, 2013

\begin{abstract}
Jatropha curcas L. (Euphorbiaceae) is important for biofuel production and as a feed ingredient for animal. However, the presence of phorbol esters in the oil and cake renders the seeds toxic. The toxicity of $J$. curcas oil is currently assessed by testing in animals, leading to their death. The identification of toxic and nontoxic improved varieties is important for the safe use of $J$. curcas seeds and byproducts to avoid their environmental toxicity. Hence, the aim of this study was to propose a short-term bioassay using a plant as a model to screen the toxicity of $J$. curcas oil without the need to sacrifice any animals. The toxicity of $J$. curcas oil was evident in germination, root elongation and chromosomal aberration tests in Lactuca sativa. It was demonstrated that $J$. curcas seeds contain natural compounds that exert phyto-, cyto- and genotoxic effects on lettuce, and that phorbol esters act as aneugenic agents, leading to the formation of sticky chromosomes and c-metaphase cells. In conclusion, the tests applied have shown reproducibility, which is important to verify the extent of detoxification and to determine toxic doses, thus reducing the numbers of animals that would be used for toxicity tests.
\end{abstract}

Key words: chromosomal aberration, germination rate, Lactuca sativa, phorbol esters, root elongation.

\section{INTRODUCTION}

Jatropha curcas L. (Euphorbiaceae) has been considered to be one of the most promising oilseeds for biofuel production (Devappa et al. 2012, Li et al. 2010). The seeds contain about $35-45 \%$ of oil, depending on the variety, and can be converted into biodiesel of high quality upon transesterification (Li et al. 2010, Rakshit et al. 2008). In addition, the plant seed could be use in animal (monogastric

Correspondence to: Milene Miranda Praça Fontes

E-mail: milenemiranda@yahoo.com.br and ruminant) nutrition as feed formulations since the kernel meal resulting from the extraction of the oil is rich in protein (30-32\% of total crude protein) and essential amino acids (Makkar et al. 1997).

However, despite their advantages, the seeds are reported to contain anti-nutritional factors such as saponin, phytate, trypsin and amylase inhibitor, cyanogenics glucosides, curcina and phorbol esters (PEs) (Rakshit et al. 2006, 2008). The latter two compounds are considered the main toxic components, then seeds become non edible 
and their presence or absence in different varieties classified it in toxic and nontoxic (Silva et al. 2012, King et al. 2009). The solubility of the phorbol esters permits their extraction along with the oil. However, these substances also remain in the cake due to the mechanical mechanism of extraction that does not completely remove the oil from the grains (Mendonça and Laviola 2009).

The first studies on the toxicity of $J$. curcas oil were carried out by force-feeding test animals with raw or defatted seed meals or even leaves and extract (Li et al. 2010). Recently, some authors proposed in vitro bioassays to evaluate the activity of toxic components as far as the variety of the toxic components of $J$. curcas oil and the extent of its detoxification by testing in animals, such as mice and rats, and in lower organisms including snail, brine shrimp and daphnia (Devappa et al. 2012, Silva et al. 2012, Li et al. 2010, Rakshit et al. 2008, Makkar and Becker 1999). Unfortunately, assessments were mainly done with the help of histopathological studies on the organs of the dead animals and by determining mortality rates. Thus, the use of a cytogenetic bioassay using a plant as a test system to rapidly screen the ecotoxicity of $J$. curcas oil could be an alternative to the techniques described above without the necessity of killing the test animals used in the study.

Plant root tip bioassays have been widely used to assess the biological effects of simple or compound substances in complex organisms and are considered to be an important tool in identifying the effects of substances on the cell cycle and also at the chromosomal level (Sousa et al. 2010, Campos et al. 2008, Dragoeva et al. 2008). The advantages of using plants as models for the study are: low cost, the ease of handling and the sensitivity, which is equal to that of other tests used for the same purpose (Andrade et al. 2010). Assessment of the changes in the cell cycle allows verification as to whether the test substance/ compound is genotoxic, mutagenic or carcinogenic (Leme and Marin-Morales 2009). Furthermore, plant cytotoxic bioassays have a good correlation with mammalian test systems (Fiskesjö 1985, Jovtchev et al. 2002, Yi and Meng 2003, Çelik and Aslantürk 2006, 2007, Lubini et al. 2008). According to Sousa and Viccini (2011), Allium cepa, Zea mays, Vicia faba, Tradescantia, Nicotiana tabacum, Crepis capillaris and Hordeum vulgaris have been the most common plant species used for cytogenotoxicity evaluations. Campos et al. (2008) reported that the high number of seeds, the high degree of contact with the solution in study, the high sensitivity and the bigger chromosomes of Lactuca sativa (lettuce) made this plant very useful for cytogenetic analysis. Bioassay using lettuce seeds are defined as static and can be used to assess acute toxicity (Andrade et al. 2010). The effects of pure compounds or complex mixtures on seed germination and seedling development of L. sativa have been evaluated during the first five days of growth (within $120 \mathrm{~h}$ of exposure) (Torres 2003). L. sativa is therefore an appropriate system in which to perform cytogenetic and root growth tests: the mitotic index (MI) reflects the frequency of cell division at different karyokinetic stages and is an important parameter in determining the rate of root growth (Andrade et al. 2010).

In summary, there are no reports, to date, of plant bioassays that have been used to detect the toxic effects of the $J$. curcas oil. However, there is great interest in identifying toxic and nontoxic improved varieties of $J$. curcas to safely use its seeds and byproducts, to avoid environmental toxicity and to increase the value of these byproducts. Thus, the aim of this study was to evaluate the effects of $J$. curcas oil on seed germination, root growth and the cell cycle of L. sativa to establishing a screening test to evaluate the toxicity of the oil without sacrificing animals.

\section{MATERIALS AND METHODS}

MATERIALS

$J$. curcas seeds (toxic Brazilian variety) were used for oil extraction. The oil was cordially supplied 
by Dr. Bruno Galvêias Laviola from the Empresa Brasileira de Pesquisa Agropecuária (EMBRAPA Agroenergia, Brasilia, DF).

$J$. curcas oil was extracted according to Makkar et al. (1997) with modifications. The ground seeds were placed in a standard Accelerated Solvent Extractor ASE 350 (Dionex, USA) using the solvent tetrahydrofuran which was evaporated under a flow of nitrogen. The oily residue was transferred to a $10 \mathrm{~mL}$ test tube, extracted four times with methanol $(2 \mathrm{~mL}+1 \times 3 \times 1 \mathrm{~mL})$, transferred to a $5 \mathrm{~mL}$ volumetric flask and the total volume made up to $10 \mathrm{~mL}$ with methanol.

\section{PLANT BIOASSAYS}

Seeds of $L$. sativa $\mathrm{L}$. $(2 \mathrm{n}=2 \mathrm{x}=18)$ of the commercial cultivar "Americana Grandes Lagos" (Isla Sementes) were used as test system material for plant bioassays in order to evaluate the toxic effects of J. curcas oil.

\section{TREATMENT SOLUTIONS}

$J$. curcas crude oil was mixed with water by intense agitation and quickly applied on germination paper in a Petri dish $(120 \mathrm{~mm})$. Six concentrations of oil were tested for their toxicity: $\left(\mathrm{JC}_{1}=5, \mathrm{JC}_{2}=20\right.$, $\mathrm{JC}_{3}=35, \mathrm{JC}_{4}=50, \mathrm{JC}_{5}=65, \mathrm{JC}_{6}=80$ and $\mathrm{JC}_{7}=$ $100 \%$ of oil). Distilled water was used as negative control solution.

\section{GERMINATION AND RoOT GROWTH ANALYSIS}

L. sativa seeds were placed on germination paper previously moistened with $5 \mathrm{~mL}$ of the test solutions. The seeds were placed in Petri dishes covered with aluminum paper to protect the seeds from any light, and the dishes were incubated in a germination chamber maintained at $24 \pm 2^{\circ} \mathrm{C}$ throughout the period of experiment. The treatments were arranged in a completely random design with four replicates for each treatment solution. Each replicate included three Petri dishes, each dish containing fifty seeds. Germination rate (GR) was calculated as the percentage of germinated seeds (radical protrusion) after 8, 16, 24, 32, 40 and $48 \mathrm{~h}$ after initial exposure. The germinated seeds in each Petri dish for each treatment were counted and compared to those seen in the control samples (distilled water).

Root growth $(\mathrm{RG})$ was measured after 48 $\mathrm{h}$ of exposure to the test solutions, with root length being measured with a digital caliper. The percentage of RG inhibition was calculated by comparing the root lengths for each treatment solution with those observed for the control. An RG curve was plotted with root length on the $Y$ axis and the different treatment doses of the oil on the $\mathrm{X}$ axis, and the inhibition concentration $50 \quad\left(\mathrm{IC}_{50}\right)$ value was calculated from the concentration of the test solution that gave $50 \%$ of $\mathrm{RG}$ reduction relative to that observed for the control. All the experiments described here were performed three times.

CYTOGENETIC ANALYSIS

At least 5 roots per Petri dish per treatment were collected after the root length measurements (48 $\mathrm{h}$ after exposure). The roots were fixed in a fresh, cold solution of ethanol and acetic acid $(3: 1 \mathrm{v} / \mathrm{v})$. Fixed root tips were hydrolyzed in $1 \mathrm{~N} \mathrm{HCl}$ at $60^{\circ} \mathrm{C}$ for $10 \mathrm{~min}$ and squashes were prepared with acetic orcein $(2 \%)$. Twelve roots per treatment (each root from one Petri dish) were used to prepare the slides. The slides were analyzed under a light microscope and about 10000-15000 cells per treatment were scored. The following parameters were analyzed: (i) mitotic index (MI), calculated as the number of dividing cells as a fraction of the total number of cells; (ii) chromosomal aberrations (CA), expressed as the percentage of number of aberrations c-metaphase cells, sticky chromosomes, bridges, and laggards - divided by the total number of cells; and nuclear aberrations (NC), determined by the frequency of condensed nuclei and micronucleated cells in interphase. 


\section{STATISTICAL ANALYSIS}

Data were subjected to one-way analysis of variance (ANOVA), and the averages of all analyzed parameters (GR, RG, MI and nuclear / chromosomal / mitotic alterations) were compared by using Tukey's or the Kruskall-Wallis test at a level of 5\% probability. A regression curve was obtained for RG data. Statistical analysis was performed by using the " $R$ " statistical program (R Development Core Team 2011).

\section{RESULTS}

\section{GERMINATION AND ROOT GROWTH ANALYSIS}

The effects of $J$. curcas oil on the germination of lettuce are given in Table I. GR measurements were taken after $8,16,24,32,40$ and $48 \mathrm{~h}$ of exposure. The results showed that $J$. curcas oil solutions caused dose-dependent decreases in the GR of lettuce. After $16 \mathrm{~h}$ of exposure, seed germination was first noticed for control as well as for JC1, JC2, JC3 and JC4. Significant differences in GR were observed for JC3 (35\% of oil) after $48 \mathrm{~h}$ of exposure relative to $100 \%$ germination for the control. The crude oil ( $\mathrm{JC} 7=100 \%)$ totally inhibited the germination of the seeds, whereas JC6 (80\%) resulted in 80\% inhibition of seed germination.
Root growth was also inhibited by $J$. curcas oil (Figure 1) in a dose-dependent manner. The lowest concentration (5\%) caused a significant decrease of approximately $20 \%$ in the root length whereas $81 \%$ decrease in root length was observed for JC6 (80\% of oil). An RG graph (root length x oil solution concentration / treatments) was plotted and a regression curve was obtained $(y=-0.0859 x$ $+8.4588 ; \mathrm{R}^{2}=0.9544$ ) (Fig. 1). It was observed that the threshold of inhibition was at the concentration of $5 \%$ of $J$. curcas oil. $\mathrm{EC}_{50}$ of root growth inhibition was calculated to be $44.57 \%$ of the oil, and the maximum inhibition threshold was $98.47 \%$.

\section{CYTOGENETIC ANALYSIS}

The effects of $J$. curcas oil on MI are summarized in Table II. Exposure to J. curcas oil inhibited MI in a dose-dependent manner. High numbers of mitotic cells were observed in control root tip cells. There was a significant decrease in MI after exposure to the oil, with the mitodepressive effects $(35 \%$ inhibition) being observed even when just $5 \%$ of the oil was present in the test solution. Additionally, a $50 \%$ reduction in $\mathrm{MI}$ was observed after incubation in a $20 \%$ solution, whereas $71.86 \%$ reduction in MI was observed with the highest concentration of the oil $(80 \%)$, relative to the control.

TABLE I

Germination Rate (GR) in $L$. sativa after $J$. curcas oil exposure.

\begin{tabular}{|c|c|c|c|c|c|c|c|c|c|c|}
\hline \multirow{2}{*}{ Treatment } & \multicolumn{2}{|c|}{ GR 16 h (\%) } & \multicolumn{2}{|c|}{ GR 24 h (\%) } & \multicolumn{2}{|c|}{ GR 32 h (\%) } & \multicolumn{2}{|c|}{ GR 40 h (\%) } & \multicolumn{2}{|c|}{ GR 48 h (\%) } \\
\hline & Mean & SD & Mean & SD & Mean & SD & Mean & SD & Mean & SD \\
\hline Control & 44.44 & 3.30 & 88.88 & 0.80 & 91.78 & 0.80 & 95.12 & 0.60 & 96.22 & 0.40 \\
\hline $\mathrm{JC} 1$ & 38.88 & 2.10 & 83.10 & 1.10 & 84.22 & 1.10 & 88.00 & 0.70 & 93.10 & 0.30 \\
\hline $\mathrm{JC} 2$ & $21.78^{*}$ & 1.30 & 76.00 & 1.70 & 84.88 & 1.30 & 88.00 & 1.00 & 88.88 & 0.90 \\
\hline $\mathrm{JC} 3$ & $2.66^{*}$ & 0.20 & $42.66^{*}$ & 3.30 & $56.44 *$ & 3.00 & $66.00^{*}$ & 2.60 & $75.34 *$ & 1.60 \\
\hline $\mathrm{JC} 4$ & $1.34^{*}$ & 0.10 & $52.00 *$ & 1.80 & $66.88^{*}$ & 2.50 & $70.44 *$ & 2.60 & $74.66^{*}$ & 2.30 \\
\hline JC5 & $0.00^{*}$ & 0.00 & $16.44 *$ & 1.30 & $21.34 *$ & 3.10 & $24.22 *$ & 3.40 & $31.10^{*}$ & 4.10 \\
\hline JC6 & $0.00^{*}$ & 0.00 & $15.34 *$ & 2.20 & $16.88^{*}$ & 2.80 & $18.66^{*}$ & 2.90 & $19.34 *$ & 3.00 \\
\hline $\mathrm{JC} 7$ & $0.00^{*}$ & 0.00 & $0.00 *$ & 0.00 & $0.00^{*}$ & 0.00 & $0.00 *$ & 0.00 & $0.00 *$ & 0.00 \\
\hline $10 \%$ red. & 40.0 & & 80.0 & & 82.6 & & 85.6 & & 86.6 & \\
\hline $50 \%$ red. & 22.2 & & 44.4 & & 45.9 & & 47.6 & & 48.1 & \\
\hline
\end{tabular}

$\mathrm{SD}=$ Standard deviation. $10 \%$ red.; $50 \%$ red. $=$ reduction of $10 \%$ and $50 \%$ in relation to the control.

*Represent statistical differences $(P<0.05)$ in relation to the control. 


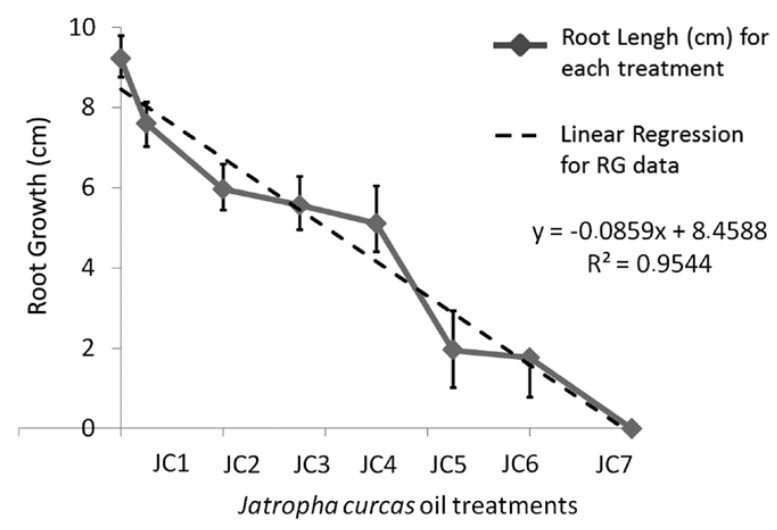

Figure 1 - Root Growth curve in L. sativa after J. curcas oil exposure Means with $(*)$ represent statistically significant differences $(P<0.05)$ relative to control according to KruskalWallis test. Bars indicate standard deviation.

Table II shows the frequencies of chromosomal and nuclear abnormalities. J. curcas oil was shown to be cytotoxic based on the total number of chromosomal aberrations and nuclear alterations induced in the treated cells. Dividing cells were observed with anaphase-telophase abnormalities such as bridges, fragments and laggards (Figure 2). The most frequent alterations were observed in metaphasis: sticky chromosomes and c-metaphase cells (Figure 2).

Moreover, alterations were observed in the normal structure of the nuclei. Strongly stained nuclei, characterized as condensed nuclei, and micronucleated cells were induced after exposure to $J$. curcas oil. The percentage of cells with these nuclear alterations increased significantly from JC1 to JC2 treatments (Table II). The frequency of cells with nuclear alterations was approximately $20 \%$ higher after incubation in $50 \%$ of oil (JC4) than in $5 \%$ of oil (JC1).

TABLE II

J. curcas oil effects on cell division in root tips of Lactuca sativa.

\begin{tabular}{ccccc}
\hline Treatments & Total number of cells analyzed & Mitotic Index & Chromosomal Alterations & Nuclear Abnormalities \\
\hline Control & 14812 & $8.85 \pm 0.99 i$ & $0.00 \pm 0.00$ & $0.00 \pm 0.00$ \\
JC1 & 10834 & $5.61 \pm 0.69 *$ & $1.09 \pm 0.87^{*}$ & $0.59 \pm 0.31$ \\
JC2 & 9647 & $3.93 \pm 0.59^{*}$ & $0.95 \pm 0.34^{*}$ & $9.11 \pm 5.49 *$ \\
JC3 & 16634 & $3.95 \pm 0.41^{*}$ & $1.28 \pm 0.83^{*}$ & $7.94 \pm 2.85^{*}$ \\
JC4 & 13142 & $3.66 \pm 0.71^{*}$ & $1.17 \pm 0.77^{*}$ & $11.35 \pm 4.61^{*}$ \\
JC5 & 14898 & $2.52 \pm 0.63^{*}$ & $1.27 \pm 0.62^{*}$ & $12.89 \pm 4.07^{*}$ \\
JC6 & 9098 & $2.49 \pm 0.91^{*}$ & $0.79 \pm 0.01$ & $5.71 \pm 1.55^{*}$ \\
\hline
\end{tabular}

${ }^{\mathrm{i}}$ Mean $\pm \mathrm{SD}$. * Significant differences in relation to the control after Kruskal-Wallis test $(P<0.05)$.

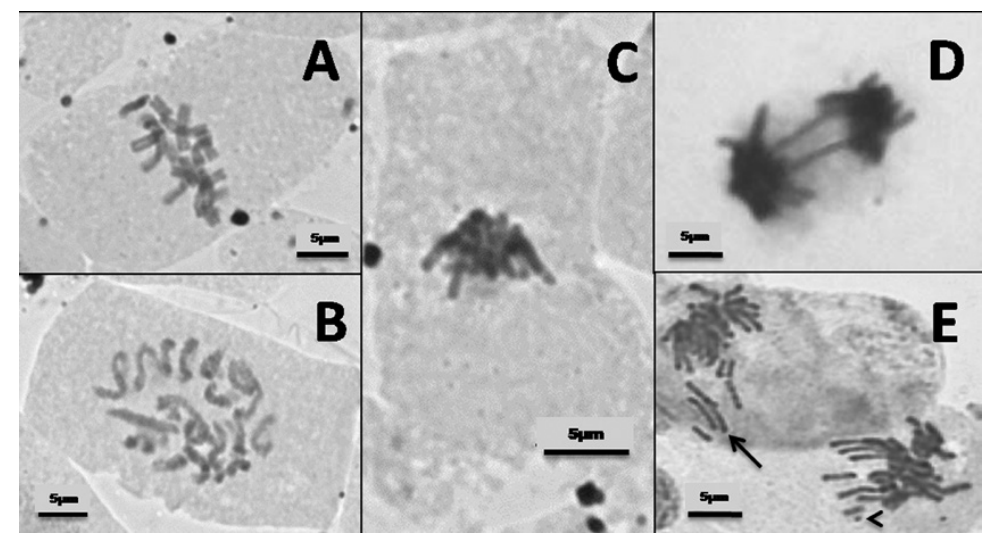

Figure 2 - Mitotic alterations induced by $J$. curcas oil in meristematic cells of L. sativa. (A) Normal metaphase. (B) C-metaphase. (C) Stickiness. (D) Bridges. (E) Fragments (head arrow) and Laggards (arrow). Bar $=5 \mu \mathrm{m}$. 


\section{DISCUSSION}

To the best of our knowledge, this is the first report of the use of a plant as a test system to detect the toxicity of $J$. curcas. Using higher plants as models allows the assessment of several endpoints. Mitodepressive effects (negative alterations in MI), micronuclei formation and chromosomal aberrations are cytogenetic data that are routinely used in cytotoxicity and genotoxicity evaluations (Chacon et al. 2002, Ferreira et al. 2003, Zanoni et al. 2005, Pugliesi et al. 2007, Sousa et al. 2010). Chromosomal aberration defines the genotoxicity of the substance / compound, whereas mitotic index (MI) and some nuclear abnormalities are used to determine cytotoxicity and analyze micronuclei to verify mutagenicity (Leme and Marin-Morales 2009). Moreover, the mechanism of action of the substance / compound on genetic material can be defined as: clastogenic (chromosome breakage) and aneugenic (chromosome lagging and effects on the spindle) (Leme and Marin-Morales 2009). Additionally, these cytogenetic data have been correlated with plant development and growth by analyzing seed germination and root elongation (Andrade et al. 2010).

Lactuca sativa is one of the test systems available to detect the effects of chemical compounds on the cell cycle of model organisms (Andrade et al. 2010). This study demonstrated that the oil extracted from $J$. curcas seeds have natural compounds that exert phyto-, cyto- and genotoxic effects on the test system. Bioassays performed, the inhibitory effects of the oil on germination and root growth of L. sativa seeds, thus demonstrating the phytotoxicity of the oil. Cell cycle analysis of meristematic cells demonstrated mitodepressive effects on the cell cycle whereas the induction of chromosomal and nuclear alterations indicated the cytogenotoxicity of the oil.

Sarkar et al. (1996) reported that, apart from inducing mutations, natural plant products may modify the action of other substances on living organisms by transforming promutagens (chemicals that are not mutagenic themselves, but that can be biologically transformed into mutagens) into mutagens. The toxic effects of the natural compounds present in J. curcas could be attributed mainly to PEs, toxic phytochemicals commonly found in plants of the Euphorbiaceae family, primarily in the genus Jatropha. The concentrations of these compounds may vary according to the genetic characteristics of the plant; $J$. curcas oil has been reported to contain $70-75 \%$ of PEs (Devappa et al. 2010). PEs are soluble in lipids and are extracted together with the oil at doses between 0.3 and 0.6 $\mathrm{mL}$. Thus, both the inhibition of germination and the reduction of root elongation could be explained by $\mathrm{PE}$ toxicity observed at higher concentrations of the oil in the emulsions prepared for treatment. Furthermore, the decrease in root growth is closely related to the reduction in MI (Andrade et al. 2010), which is reflected in the percentage of dividing cells. Strong inhibition of root length and decrease in the number of dividing cells were observed in this study. These two parameters, cell division and growth, are intimately intertwined in plants, growth involves cell proliferation (Harashima and Schnittger 2010). PEs are diterpene analogs of diacylglycerol, an activator of many isoforms of protein kinase - C (PKC) (Zhang et al. 1995, King et al. 2009), which is a cell protein that acts as a regulator of many cellular processes, including phase transition in the cell cycle. Hence, the effects of $J$. curcas oil could be explained by the similarity in the action of PEs to that of diacylglycerol in cells. Diacylglycerol has a short half-life in the cell: activation of PKC is usually only temporary. PKC activation by PEs, however, is much longer (Griner and Kazanietz 2007, King et al. 2009) and leads to a number of biological activities, such as chromatin dysfunction induced by interactions between DNA and toxic compounds (Glinská et al. 2007, Andrade et al. 2010). Thus, this alteration of 
cell cycle regulation by PEs may be associated with the reduction in MI observed after treatments.

Apart from the cytotoxicity of $J$. curcas oil indicated by the decrease in MI, genotoxic effects were also observed, since a great number of chromosomal aberrations were induced with increasing oil concentration. Cytogenotoxic effects of $J$. curcas oil on lettuce root tips are shown in Table II. It includes different kinds and numbers of chromosomal aberrations in the root tip meristematic cells. Among the chromosomal alterations observed in anaphase-telophase cells in this study, we highlight the presence of bridges, chromosomes and laggards. Nevertheless, the most frequent alterations were observed in metaphase: stickiness of chromosomes in metaphase and c-metaphase cells. These dose-independent changes were observed at all concentrations of the oil (Table II).

The presence of sticky chromosomes reflects the genotoxic effects of $J$. curcas oil, since sticky chromosomes represent a change in the chromosomal structure, which leads to the loss of the characteristics of normal chromosomal condensation and causes agglomerate formation (Babich et al. 1997). The appearance of the chromosomes is sticky due to the action of toxic compounds on the physico-chemical structure of DNA and / or protein, leading to complex formation with phosphate groups in DNA, condensation of the DNA or the formation of inter- and intrachromatid links (El-Ghamery et al. 2003). This change is irreversible and generally leads to cell death. The occurrence of strongly stained nuclei throughout this study, characterized as condensed nuclei, is also an alteration of the normal structure of the nuclei. Nuclear condensation is a feature that is associated with the process of programmed cell death (Andrade et al. 2010). These data demonstrate the toxic action of the J. curcas oil at a cellular level. Another alteration commonly observed in treated cells was c-metaphase, which got this name based on the observation of chromosomes around the equator of the cell in a manner similar to that seen in cells treated with colchicine. The observation of c-metaphase cells indicates the action of the toxic agent on the spindle fibers, preventing the continuation of the mitotic cycle (Leme and Marin-Morales 2009). As a result of this disorder, the cell cycle is interrupted in metaphase and the chromosomes are seen scattered and condensed with very well-defined centromeres (Fiskejö 1985). Both sticky chromosomes and c-metaphase cells are abnormalities that characterize the aneugenic action of the components of the J. curcas oil.

Nuclear alterations (condensed nuclei and micronucleated cells) were also observed and the percentage of cells with such alterations increased significantly for the different treatments. As stated earlier, nuclear changes, such as chromatin condensation, indicate that cells undergo programmed cell death (Andrade-Vieira et al. 2011). The interaction of PEs with DNA and other cellular components can activate the molecular machinery, leading to cell death. Other nuclear alterations observed in this study were micronuclei, which probably arose from both clastogenic and aneugenic actions of the $J$. curcas oil. Considering the high frequency of cells arising from the aneugenic action of $J$. curcas oil, the majority of micronuclei observed may have derived from a single chromosome that was lost from the whole set of chromosomes in the cell (Campos et al. 2008).

The toxicity of $J$. curcas seeds has been examined with various bioassays by using animals such as cattle, goats and fish as test systems. The goals of such bioassays lie in the interests of using the plant seed for biodiesel production and in animal nutrition, and hence, in making its use more economically viable. However, the presence of toxic compounds in the cake can lead to death of the animals, depending on the amount of seed used. This was demonstrated by Mendonça and Laviola (2009) through the testing of acute and chronic doses of seeds in ruminants. Acute doses of 
$2.5 \mathrm{~g} \mathrm{seed} / \mathrm{kg}$ body weight/day and chronic doses of $0.025 \mathrm{~g} \mathrm{seed} / \mathrm{kg}$ body weight/day for 14 days resulted in the death of all the animals. Devappa et al. (2012) conducted tests to evaluate the activity of PEs present in the $J$. curcas seeds in three aquatic species-based bioassays (snail, brine shrimp (artemia) and daphnia) and in microorganisms. These authors demonstrated increased mortality with increasing concentrations of PEs in all the bioassays tested, with $\mathrm{EC}_{50}(48 \mathrm{~h})$ values of 0.33 , 26.48 and $0.95 \mathrm{mg} \mathrm{L}^{-1}$ for the PEs in snail, artemia and daphnia, respectively. Among the bacterial species tested, Streptococcus pyogenes and Proteus mirabilis were highly susceptible with a minimum inhibitory concentration of $215 \mathrm{mgL}^{-1}$ of PEs. The snail bioassay was most sensitive with $100 \%$ snail mortality at $1 \mu \mathrm{g}$ of PEs $\mathrm{mL}^{-1}$. Rakshit et al. (2008) tested $J$. curcas oil toxicity in rats by feeding treated and untreated meal through their diet. Treated meal consisted of whole and dehulled seed meal in which PE content was reduced up to $89 \%$ by subjecting the cake of the whole and dehulled seeds to alkali and heat treatments to deactivate the PE as well as lectin content. Regardless of the treatment, all rats showed reduced appetite and diet intake was low, accompanied by diarrhea. The rats also exhibited reduced motor activity. However, the rats fed with treated meal exhibited delayed mortality when compared to rats fed untreated meal.

The present study is the first one to use a plant bioassay to test the toxicity of $J$. curcas oil. The L. sativa test was a fast and sensitive assay to detect genotoxic and mutagenic compounds in $J$. curcas seed extracts. It has been demonstrated that $J$. curcas seeds have natural compounds that exert phyto-, cyto- and genotoxic effects on lettuce and that PEs, the main compounds in the oil, act as aneugenic agents leading to the formation of sticky chromosomes and c-metaphase cells. In addition, the tests applied have shown reproducibility, an important quality to verify the quality of detoxification and the determination of toxic doses, protecting animals from direct exposure to this test, and hence, avoiding their death.

\section{ACKNOWLEDGMENTS}

The authors thank Fundação de Amparo à Pesquisa do Estado do Espírito Santo (FAPES), Conselho Nacional de Desenvolvimento Científico e Tecnológico (CNPq) and Coordenação de Aperfeiçoamento de Pessoal de Nível Superior (CAPES) for the financial support.

\section{RESUMO}

Jatropha curcas L. (Euphorbiaceae) é importante para a produção de biocombustíveis e como ingrediente de ração para animais. No entanto, a presença de ésteres de forbol no óleo e na torta tornam as sementes tóxicas. A toxicidade do óleo de $J$. curcas é frequentemente acessada através de testes em animais, levando-os à morte. A identificação de variedades melhoradas tóxicas e não tóxicas é importante para a utilização segura das sementes de J. curcas e subprodutos para evitar a sua toxicidade ambiental. Sendo assim, o objetivo deste estudo foi propor um bioensaio, rápido usando uma planta como um modelo para avaliar a toxicidade do óleo de $J$. curcas, sem a necessidade de sacrificar nenhum animal. A toxicidade do óleo de J. curcas foi evidente na germinação, no crescimento radicular e nos testes de aberrações cromossômicas em Lactuca sativa. Foi demonstrado que as sementes de $J$. curcas contêm compostos naturais que exercem efeitos fito-, cito e genotóxicos na alface, e que os ésteres de forbol atuam como agentes aneugênicos, levando à formação de células com cromossomos pegajosos e c-metáfase. Em conclusão, os testes aplicados demonstraram reprodutibilidade, o que é importante para verificar a extensão da desintoxicação e para determinar doses tóxicas, reduzindo assim o número de animais que seriam utilizados para os testes de toxicidade.

Palavras-chave: aberração cromossômica, razão de germinação, Lactuca sativa, éster de forbol, crescimento radicular. 


\section{REFERENCES}

Andrade LF, Davide LC And Gedraite LS. 2010. The effect of cyanide compounds, fluorides, aluminum, and inorganic oxides present in spent pot liner on germination and root tip cells of Lactuca sativa. Ecotox Environ Saf 73: 626-631.

Andrade-Vieira LF, Gedraite LS, CAMpos JMS AND DAVIDE LC. 2011. Spent Pot Liners (SPL) induced DNA damage and nuclear alterations in root tip cells of Allium cepa as a consequence of programmed cell death. Ecotox Environ Saf 74: 882-888.

Babich H, Segall MA AND Fox KD. 1997. The Allium test - a simple, eukaryote genotoxicity assay. Am Biol Teach 59: 580-583.

CAMPoS JMS, Viccini LF, ANDRADE LF, DAVIDE LC AND RoDRIGUeS GS. 2008. Genetic Toxicology and Environmental Mutagenesis in Allelopathic Interactions. In: Plant Bioassays. Ed. Houston: Studium Press, 344 p.

ÇELIK TA AND ASLANTÜRK OS. 2006. Anti-mitotic and antigenotoxic effects of Plantago lanceolata aqueous extracts on Allium cepa root tip meristem cells. Biologia 61: 693-697.

ÇELIK TA AND ASLANTÜRK OS. 2007. Cytotoxic and genotoxic effects of Lavandula stoechas aqueous extracts. Biologia 62: 292-296.

Chacon DR, Dalla-Libera AN, Cintra DEC, Carvalho JCT, OLIVEIRA GA AND MAISTRO EL. 2002. Absence of genotoxic and antigenotoxic effects of a standardized extract of the medicinal plant Solanum melongena on peripheral blood and bone marrow cells of Wistarrats. Cytologia 67: 417-422.

DEVAPPA RK, MAEs J, MAKKer HPS, GREYT W AND BECKeR K. 2010. Quality of biodiesel prepared from phorbol ester extracted Jatropha curcas oil. J Am Oil Chem Soc 87: 697-704.

DEVAPPA RK, RAJESH SK, KUMAR V, MAKKAR HPS AND BECKER K. 2012. Activities of Jatropha curcas phorbol esters in various bioassays. Ecotox Environ Saf 78: 57-62.

Dragoeva AP, NANOVA ZD AND KALChEVA VK. 2008. Allelopathic activity of micropropagated Orlganum vulgare ssp. hirtum and its effect on mitotic activity. Allelopath J 22: 131-142.

El-GHAMERY AA, El-Kholy MA AND EL-YousSer MAA. 2003. Evaluation of cytological effects of $\mathrm{Zn}^{2+}$ in relation to germination and root growth of Nigella sativa L. and Triticum aestivum L. Mutat Res 537: 29-41.

Ferreira L, CARvalho JCT AND Maistro EL. 2003. Standardized Solanum melongena extract presents protective effects against chromosomal aberrations induced by Doxorubicin in Wistar rat bone marrow cells. Cytologia 68: 177-181.

FISKESJÖ G. 1985. The Allium test as a standard in environmental monitoring. Hereditas 102: 99-112.

GLinSKÁ S, BARTCZAKA M, OLEKSIAKA S, WOLSKAA A, GabaraA B, Posmykb M and Janasb K. 2007. Effects of anthocyanin-rich extract from red cabbage leaves on meristematic cells of Allium cepa L. roots treated with heavy metals. Ecotox Environ Saf 68: 343-350.
GRINER EM AND KAZANIETZ MG. 2007. Protein kinase c and other diacylglycerol effectors in cancer. Nat Ver Cancer 7: 281-294.

HARASHIMA H AND SCHNITTGER A. 2010. The integration of cell division, growth and differentiation. Curr Opin Plant Biol 13: 66-74.

Jovtchev G, Stergios M And Schubert I. 2002. A comparison of $N$-methyl- $N$-nitrosourea-induced chromatid aberrations and micronuclei in barley meristems using FISH techniques. Mutat Res 517: 47-51.

King AJ, He W, Cuevas JA, Freudenberger M, Ramiaramanana D AND GRAHAM IA. 2009. Potential of Jatropha curcas as source of renewable oil and animal feed. J Exp Bot 60: 2897-2905.

LEME DM AND MARIN-Morales MA. 2009. Allium cepa test in environmental monitoring: A review on its application. Mutat Res 682: 71-81.

Li CY, DEVAPPA RK, LIU JX, MAKKAR HPS AND BECKER K. 2010. Toxicity of Jatropha curcas phorbol esters in mice. Food Chem Toxicol 48: 620- 625.

Lubini G, Fachinetto JM, Laughinghouse IV HD, Paranhos JT, Silva ACF AND Tedesco SB. 2008. Extracts affecting mitotic division in root-tip meristematic cells. Biologia 63: 1-5.

MAKKAR HPS AND BECKER K. 1999. Nutricional studies on rats and fish (carp Cyprinus capio) fed diets containing unheated and heated Jatropha curcas meal of a non-toxic provenance. Plant Food Hum Nutr 53: 183-192.

MAKKAR HPS, BECKER K, SPORER F AND WinK M. 1997. Studies on nutritive potential and toxic constituents of different provenanaces of Jatropha curcas. J Agr Food Chem 45: 3152-3157.

Mendonça S And LaViola BG. 2009. Uso Potencial e Toxidez da Torta de Pinhão-manso. Comunicado técnico, Embrapa Agroenergia, Brasilia, $8 \mathrm{p}$.

Pugliesi GC, Andrade SF, Bastos JK AND Maistro EL. 2007. In vivo clastogenicity assessment of the Austroplenckia opulnea (Celastraceae) leaves extract using micronucleus and chromosomes aberration assay. Cytologia 72: 1-6.

R Development Core Team. 2011. R: A Language and Environment for Statistical Computing. R Foundation for Statistical Computing, Vienna, Austria.

RAKSHIT KD, MADHVI D AND BHAGYA S. 2006. Jatropha curcas - a potential source of protein in food/feed. In: Symposium on Rural Food and Nutrition. Organized by Sole Company and Central Food Technological Research Institute, Mysore, India, March 22 ${ }^{\text {nd }}, 2005$.

RAKSHIT KD, DARUKESHWARA J, RATHINA RAJ K, NARASIMHAMURTHY K, SAIBABA P AND BHAGYA S. 2008. Toxicity studies of detoxified Jatropha meal (Jatropha curcas) in rats. Food Chem Toxicol 46: 3621-3625.

SARKAR D, SHARMA A AND TALUKDER G. 1996. Plant extracts as modulators of genotoxic effects. Bot Rev 62: 275-300.

SILVA GN, FARONI LRA, SOUSA AH AND FREITAS RS. 2012. Bioactivity of Jatropha curcas L. to insect pests of stored products. J Stored Prod Res 48: 111-113. 
SoUSA SM, SILVA OS AND VICCINI LF. 2010. Cytogenotoxicity of Cymbopogon citratus (DC) Stapf (lemon grass) aqueous extracts in vegetal test systems. An Acad Bras Cienc 82: 305-311.

SousA SM AND VicCINI LF. 2011. Cytotoxic and genotoxic activity of Achillea millefolium aqueous extracts. Rev Bras Farmacog 21: 98-104.

TORRES RMT. 2003. Empleo de los ensayos con plantas en el control de contaminantes tóxicos ambientales. Rev Cubana Hig Epidemiol 41: 2-3.

YI H AND MENG Z. 2003. Genotoxicity of hydrated sulfur dioxide on root tips of Allium sativum and Vicia faba. Mutat Res 537: 109-114.
ZANONI JN, Freitas P, PEREIRA RVF, PEREIRA MAS AND MIRANDA-NETO MH. 2005. Effects of supplementation with ascorbic acid for a period of 120 day on the miosin-V and NADPHd positive myenteric neurons of the ileum rats. Anat Histol Embyol 34: 149-153.

Zhang G, Kananietz MG, Blumberg PM AND Hurley JH. 1995. Crystal structure of the Cys2 activator-binding domain of protein kinase $\mathrm{Cd}$ in complex with phorbol ester. Cell 81: 917-924. 